\title{
Investigation of PH-Assisted Human Serum Albumin (HSA)-Cobalt (Co) Binding Using Nanomechanical Deflection and Circular Dichroism
}

\author{
Garima Thakur ${ }^{1 *}$, Seonghwan Kim ${ }^{1,2}$, Kovur Prashanthi ${ }^{1}$ and Thomas Thundat ${ }^{1}$
}

${ }^{1}$ Department of Chemical and Materials Engineering, University of Alberta, Edmonton, AB, T6G 2V4, Canada

${ }^{2}$ Department of Mechanical and Manufacturing Engineering, University of Calgary, Calgary, AB, T6G 2V4, Canada

\begin{abstract}
Human serum albumin (HSA)-cobalt (Co) binding assay could serve as a marker for early detection of myocardial ischemia. However, the binding mechanism of the HSA-Co assay is very complex and hard to detect. During myocardial ischemia, the physiological $\mathrm{pH}$ may change with subsequent decrease in binding of Co with HSA. In this paper, we have investigated the binding of Co with HSA functionalized on the surface of microcantilever at acidic, basic and neutral pHs. Conformational change of HSA upon injection of $\mathrm{Co}$ (II) ions resulted in deflection of cantilever sensors. Furthermore, spectroscopic insight was obtained using circular dichroism to analyze conformational change of HSA-Co(II) binding.
\end{abstract}

Keywords: Biomarker; Cobalt, Conformation; Human serum albumin; Microcantilever; Nanomechanical sensors; Spectroscopy

\section{Introduction}

Human serum albumin (HSA) is a protein that is abundantly present in blood plasma and is extensively studied. ${ }^{1}$ It plays an important role in developing colloidal osmotic pressure and controlling $\mathrm{pH}$ in blood circulation [1-3]. The HSA is well-known to be a transporter of various physiological metal ions such as $\mathrm{Ca}^{2+}, \mathrm{Zn}^{2+}, \mathrm{Co}^{2+}$, and $\mathrm{Cu}^{2+}$ as well as a carrier of variety of lipids and drugs [4-9]. The wide-ranging specificity of HSA can be attributed to the presence of distinct binding sites [5-8]. However, $\mathrm{Co}^{2+}$ binding has recently attracted much attention mainly due to its potential of becoming a cardiac biomarker to measure myocardial ischemia, which is a condition that precedes myocardial necrosis [10-16]. Decrease in binding ability of Co ions to ischemia modified albumin can assist in developing a biosensor comparable to or better than electrocardiogram (ECG) diagnosis [17]. Literature currently reports only one clinical assay (albumin cobalt binding (ACB) test), which is a calorimetric test, and it is known to lack specificity [17-20].

Cardiac diseases, such as myocardial infarction and necrosis are the leading cause of death worldwide, especially in developing countries [21]. Portable sensors that are highly sensitive and selective are required for diagnostic purposes in resource-limited countries. One of the versatile diagnostic tools with promising future is the microcantilever sensor platform. Conformational changes in protein molecules induced by binding of analytes such as metal ions or other target molecules are capable of sensitively altering the microcantilever bending [2229]. Microcantilever sensors have the advantage of detection of target molecules in a small volume of samples as compared to other spectroscopic and calorimetric techniques which are extensively used in for HSA-Co(II) binding. High sensitivity of the cantilevers has direct significance in early detection of diseases. Therefore, microcantilever sensors offer an opportunity for development of biosensing platforms with small volumes of samples for real-time, high sensitivity diagnosis [22,29-32]. Recently, pH-assisted conformation change of HSA was examined using microcantilever sensors, which showed the possibility of detecting conformational change of HSA by variation of $\mathrm{pH}$ using nanomechanical bending [33]. This study and many previous reports show that microcantilever sensors have the potential to be sensitive micromechanical $\mathrm{pH}$ sensors [33-36].

It is important to examine the HSA-Co(II) binding at acidic, basic and neutral $\mathrm{pH}$ because during myocardial ischemia, the physiological
pHs may change resulting in decrease in binding of $\mathrm{Co}$ (II) with HSA $[17,19,37]$. In the present study, we have examined the effect of binding of $\mathrm{Co}(\mathrm{II})$ on HSA at a solid-liquid interface and compared it with spectroscopic results obtained in liquid environment. To best of our knowledge there is no such study reported on solid-liquid interface for HSA-Co(II) binding. This study confirms that the HSA immobilized on a solid substrate, i.e. a microcantilever beam shows similar results as in a liquid environment.

\section{Materials and Methods}

\section{Materials}

All chemicals including $\mathrm{CoCl}_{2} .6 \mathrm{H}_{2} \mathrm{O}, \mathrm{NaCl}, \quad \mathrm{Na}_{2} \mathrm{PO}$ 1-ethyl-3-(3-dimethyl aminopropyl) carbodiimide (EDC), N-Hydroxysulfosuccinimide (sulfo-NHS) and 2-(N-morpholino) ethanesulfonic acid (MES) were purchased from Sigma Aldrich. Ligands carboxy-PEG ${ }_{12}$-lipoamide $\left(\mathrm{PEG}_{12}-\mathrm{CL}\right)$, and solvents such as ethanol were purchased from Fisher Scientific. Native HSA which typically contains $0.5-1.5$ moles of fatty acids bound to one mole of HAS, was purchased from Sigma Aldrich. Deionized (DI) water with resistivity of $18 \mathrm{M} \Omega \cdot \mathrm{cm}^{-1}$ from Milli-Q-water purification system was used in all the experiments. Commercially available silicon microcantilevers (Micromotive Co., Mainz, Germany) were used in all the experiments. The dimensions of the cantilever were $500 \mu \mathrm{m}$ in length, $90 \mu \mathrm{m}$ in width, and $1 \mu \mathrm{m}$ in thickness.

\section{Functionalization of the cantilevers}

Silicon microcantilevers were cleaned using piranha $\left(\mathrm{H}_{2} \mathrm{SO}_{4}\right.$ : $\mathrm{H}_{2} \mathrm{O}_{2}$ (3:1)) for $10 \mathrm{~min}$ and washed with plenty of DI water and rinsed in ethanol. After air-drying inside the hood, freshly cleaned

*Corresponding author: Garima Thakur, Department of Chemical and Materials Engineering, University of Alberta, Edmonton, AB, T6G 2V4, Canada, Tel: 780-492 8664; E-mail: garima@ualberta.ca

Received December 19, 2013; Accepted February 21, 2014; Published February 24, 2014

Citation: Thakur G, Kim S, Prashanthi K, Thundat T (2014) Investigation of PH-Assisted Human Serum Albumin (HSA)-Cobalt (Co) Binding Using Nanomechanical Deflection and Circular Dichroism. J Nanomed Nanotechol S5:008. doi:10.4172/2157-7439.S5-008

Copyright: $\odot 2014$ Thakur G, et al. This is an open-access article distributed under the terms of the Creative Commons Attribution License, which permits unrestricted use, distribution, and reproduction in any medium, provided the original author and source are credited. 
microcantilevers were coated with 5/50 $\mathrm{nm}$ Ti/Au layer using electronbeam evaporator. Freshly coated microcantilevers were then again cleaned using piranha for $30 \mathrm{~s}$ to $1 \mathrm{~min}$ and washed with DI water before rinsing in ethanol. Air dried microcantilevers were treated with $1 \mathrm{mM}$ $\mathrm{PEG}_{12}-\mathrm{CL}$ solution in $\mathrm{PBS}$ buffer $\left(20 \mathrm{mM} \mathrm{Na}_{2} \mathrm{PO}_{4}, 0.15 \mathrm{M} \mathrm{NaCl}\right)$ at $\mathrm{pH} 7.4$ for 3 hrs. Excess reagent was washed away by cleaning microcantilevers in buffer solution, followed by activation using crosslinking agent EDC and sulfo-NHS. The microcantilever was immersed in $0.2 \mathrm{M}$ EDC and $50 \mathrm{mM}$ sulfo-NHS prepared in MES buffer $(0.1 \mathrm{M} \mathrm{MES}, 0.5 \mathrm{M} \mathrm{HCl})$ at $\mathrm{pH} 6$ for at least $90 \mathrm{~min}$. Excess of the reagent was removed by washing the cantilever in buffer solution. The cantilever was then immersed in HSA $(0.2 \mathrm{mg} / \mathrm{ml})$ in PBS buffer $\mathrm{pH} 7.4$ for $3 \mathrm{hrs}$. The surface of silicon substrate coated with $\mathrm{Ti} / \mathrm{Au}(5 / 50 \mathrm{~nm})$ layer was functionalized by HSA in the same manner as described above. Cantilevers without any protein modification except self-assembled monolayer (SAM) formation on gold face of cantilever were used as reference cantilevers.

\section{Fourier transform infrared spectroscopy (FTIR)}

NEXUS 670 FTIR (Thermo Nicolet, Madison, WI, USA) was used with variable angle accessory equipped with mercury-cadmiumtelluride detector cooled using liquid nitrogen. The sample spectra of $\mathrm{PEG}_{12}$ - CL SAM and HSA modified sample substrates were carried out at an incident angle of 60 degrees with p-polarized light. The resolution was $4 \mathrm{~cm}^{-1}$ with total 200 scans.

\section{Fluorescence spectroscopy}

Fluorescence measurements were carried out on Cary EclipseVarian Fluorescence Spectrometer (Agilent Technologies, Santa Clara, CA, USA) with Xenon flash lamp. The emission and excitation slit width was set at $5 \mathrm{~nm}$ each. Excitation wavelength was $280 \mathrm{~nm}$.

\section{Circular dichroism (CD)}

The CD spectra were measured on an OLIS DSM 17 Circular Dichroism instrument (OLIS Inc. Bogart, Georgia, USA). Quartz cell of $0.02 \mathrm{~cm}$ path length was used to contain sample. The spectra were recorded in the far-UV region with wavelength between 195 and 275 $\mathrm{nm}$. The spectrum was recorded with five scan accumulations. The data was analyzed using CD pro software.

\section{Atomic force microscopy (AFM)}

Asylum MFP-3DAFM with MFP head and scanner was used for tapping mode microscopy. The protein was immobilized on silicon wafer coated with Ti/Au: 5/50 nm. Freshly prepared samples were used for AFM imaging conducted in air.

\section{Cantilever deflection measurements}
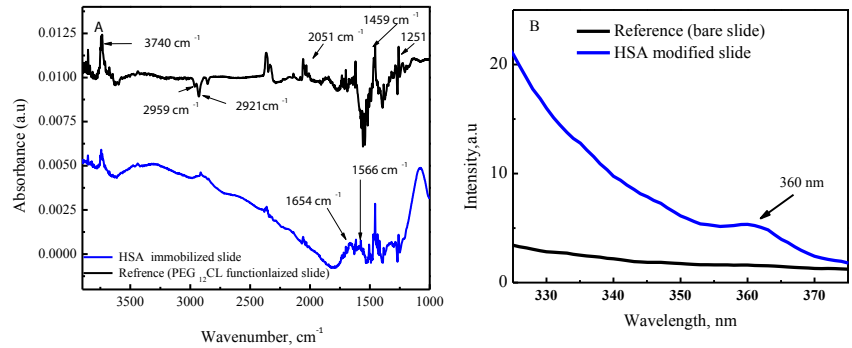

Figure 1: IR spectra of $P E G_{12}-C L$ SAM modified gold slide (black) and HSA modified gold slide (blue) (A); Fluorescence spectra of the HSA modified slide (blue) and reference gold slide (black) (B).
Cantilever deflection measurements were monitored using homemade optical beam deflection system previously reported by our group [33]. The "compressive stress" (negative deflection, towards silicon side) and "tensile stress" (positive deflection, towards gold side) of the cantilever were measured by using the laser beam reflected of the free-end of the cantilever into a position sensitive detector (PSD). The experiments were performed in a stainless steel flow cell (Scentris, Vecco, Santa Barbara, CA). The buffer solution was flowed through the cell using a syringe pump and a flow rate of $10 \mu \mathrm{L} / \mathrm{min}$. The analyte was introduced into the flow system by switching the flow using a low pressure liquid chromatography injection-port loop arrangement with a volume of $1000 \mu \mathrm{L}$ without altering the flow rate.

The principle on which microcantilever sensors detect adsorbed analytes is either resonance frequency variation using mass loading or surface stress measurements [35]. The differential surface stress variation due to molecular adsorption on one of its surfaces can be calculated using Stoney's equation [37-41]. The Stoney's formula gives the relationship between radius of curvature, $R$, and the differential surface stress, $\Delta \sigma$, induced on the microcantilever surface:

$$
\Delta \sigma=\frac{E t^{2}}{6 R(1-v)}
$$

where $E$ is Young's Modulus (168.5 GPa), $t$ is thickness of the cantilever, and $v$ is Poisson's ratio $(0.07)[35,37,42]$. This equation can be modified into a simpler expression

$$
\Delta \sigma=\frac{1}{3}\left(\frac{t}{l}\right)^{2}\left(\frac{E}{(1-v)}\right) \Delta z
$$

where $l$ is the effective length, and $\Delta z$ is the deflection of the cantilever.

The flow rate was kept constant during all the experiments. This arrangement made certain that the microcantilever was under constant flow with no change in flow rate. It should be noted that the cantilever was immersed in the buffer solution and set to stabilize at a persistent flow-rate to obtain a constant baseline.

\section{Results and Discussion}

\section{Surface characterization}

The ligand $\mathrm{PEG}_{12}-\mathrm{CL}$ was used for immobilization on the gold coated face of the cantilever. This ligand binds to the gold surface strongly forming PEG-islands [43] and provides improved flexibility to biomolecules. We have chosen PEG based crosslinking ligand to provide required sensitivity to HSA molecules as this crosslinking ligand prevents non-specific interactions, and provides more spatial orientation to HSA due dithiolate anchoring terminal towards gold face $[43,44]$. The characterization of the surface with SAM $\left(\mathrm{PEG}_{12}-\mathrm{CL}\right)$ was achieved using FTIR and fluorescence spectroscopy. The IR spectra for the immobilized SAM (Figure 1A) shows characteristic peaks for ligand (-black) at $3740 \mathrm{~cm}^{-1}\left(v_{\mathrm{s}}-\mathrm{OH}\right), 2959$ and $2921 \mathrm{~cm}^{-1}\left(v_{\mathrm{s}}-\mathrm{CH}_{2}\right)$, $1459 \mathrm{~cm}^{-1}\left(v_{\mathrm{b}}-\mathrm{C}-\mathrm{O}-\mathrm{H}\right), 1253 \mathrm{~cm}^{-1}$ (- $\mathrm{CH}_{2}$ wagging) [45]. The surface conjugation of HSA was accomplished using EDC coupling reaction and the IR spectrum (blue) (Figure 1A) showed the amide I and amide II bands at 1654 and $1566 \mathrm{~cm}^{-1}$, respectively. Moreover, there is a broad peak between 3500 and $3000 \mathrm{~cm}^{-1}$ showing extensive hydrogen bonding $[46,47]$. Figure 1B shows the fluorescence spectra of HSA modified gold substrate and the reference gold substrate, it can be clearly seen that the band at $360 \mathrm{~nm}$ is for Tryptophan (Trp) residue present in the protein [48]. The fluorescence spectra of HSA modified gold-surface suggests 

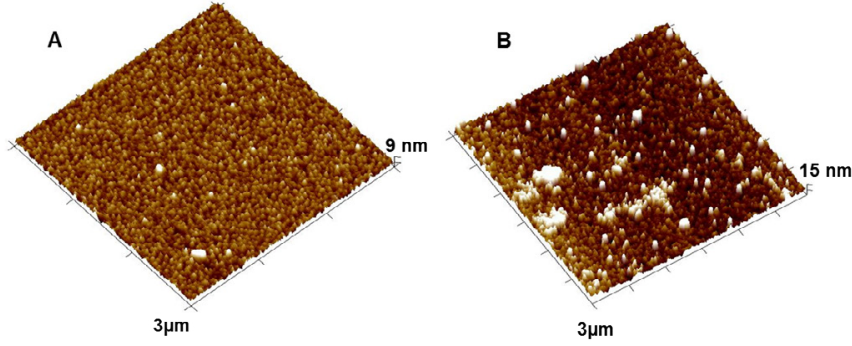

Figure 2: AFM of PEG modified gold surface (A); AFM of HSA immobilized surface roughness from $2-15 \mathrm{~nm}(\mathrm{~B})$. (shown by $3 \mathrm{D}$ images)
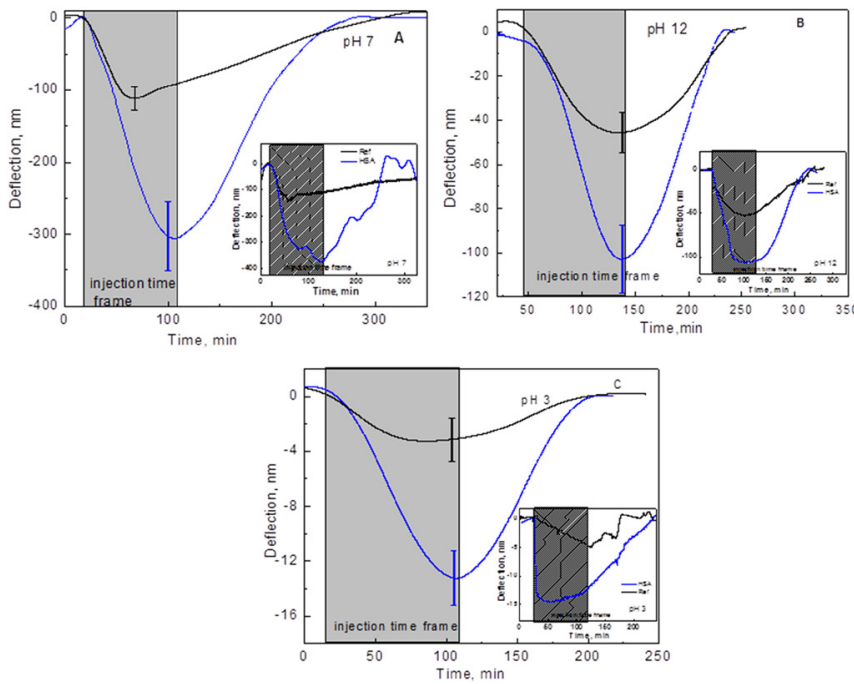

Figure 3: Average deflection of HSA immobilized cantilever (blue) and reference $\mathrm{PEG}_{12}-\mathrm{CL}$ SAM immobilized cantilever (black) upon injection of 100 $\mathrm{mM} \mathrm{CoCl}$ at various $\mathrm{pHs}$ A) $\mathrm{pH} 7$; $\mathrm{B}) \mathrm{pH} 12 ; \mathrm{C}) \mathrm{pH}$. The signals are filtered from noise by smoothening and baseline adjustment is done by subtracting a straight line in Origin Pro 8 (graphing and data analysis software). Inset shows the unfiltered cantilever signals.

that Trp residues were oriented towards the surface instead of being embedded inside the protein $[48,49]$. Moreover, the AFM images of the self-assembled PEG layers on gold substrate showed the height of approximately $1.6-2 \mathrm{~nm}$. The AFM images also showed that the SAM was organized homogeneously on the surface with island height upto 6 $\pm 4 \mathrm{~nm}$ (Figure 2A). HSA modified substrate showed height up to $16 \pm$ $4 \mathrm{~nm}$ and globular protein molecules were arranged in well-dispersed fashion on the surface (Figure 2B).

\section{pH-dependent HSA-Co (II) binding}

The deflection signals were acquired by taking the average deflection signals of cantilevers modified with HSA (blue) and average deflection signal of cantilevers modified with $\mathrm{PEG}_{12}$-CL SAM (black) (Figure 3). Reference cantilever signal was taken from $\mathrm{PEG}_{12}-\mathrm{CL}$ modified cantilever for common mode rejection. The signals were analyzed as a deflection signals after averaging the signals from at least 5 different set of cantilevers with average smoothing to reject the noise observed due to change in the refractive index. The buffer strength was optimized to $150 \mathrm{mM}$ sodium chloride and $20 \mathrm{mM}$ dibasic sodium phosphate. Only a small amount of $0.1 \mathrm{M} \mathrm{NaOH}$ or $0.1 \mathrm{M} \mathrm{HCl}$ was used to raise or lower the $\mathrm{pH}$, respectively. A flow rate of $10 \mu \mathrm{L} / \mathrm{min}$ was found to be an optimum and used for all the experiments reported in this study. After acquiring baseline $\mathrm{CoCl}_{2}(100 \mathrm{mM}, 1000 \mu \mathrm{L})$ was injected with time frame of around $100 \mathrm{~min}$.

It was revealed from our previous studies that the conformation change of HSA can be monitored by switching the $\mathrm{pH}$ using microcantilever sensors [33]. To understand the effect of $\mathrm{pH}$ on binding of $\mathrm{Co}$ (II) to HSA, we expanded this investigation further and explored potential $\mathrm{pH}$-based biosensing capabilities of cantilevers. Figure $3 \mathrm{~A}$ shows two deflection signals for $\mathrm{PEG}_{12}$-CL SAM (black) and HSA (blue) immobilized cantilevers at $\mathrm{pH} 7$ by monitoring the mean deflection of different cantilever sets upon injection of $\mathrm{CoCl}_{2}$ $(100 \mathrm{mM})$. The deflection signals match the time period of injection of $100 \mathrm{~min}$. In this case, upon injection of analyte a compressive stress was observed on the microcantilever. The bending signal reaches a maximum deflection about $100 \mathrm{~min}$ (injection time). After $100 \mathrm{~min}$ the signal returns to equilibrium value due to the washing out of the complex from both HSA and ligand immobilized cantilevers. For the $\mathrm{PEG}_{12}$-CL modified cantilever maximum deflection was $113 \pm 18 \mathrm{~nm}$ (corresponding surface stress $27 \pm 4.3 \mathrm{mN} / \mathrm{m}$ ). Binding of $\mathrm{Co}$ (II) to the protein showed the maximum deflection at $306 \pm 45 \mathrm{~nm}$ (resulting in surface stress of $73 \pm 10.8 \mathrm{mN} / \mathrm{m}$ ). These results indicate that the Co(II) binds strongly to the protein in comparison to the ligand. However, the complex ion is progressively washed away from the surface due to liquid flow as observed in all these experiments. The significant bending of the microcantilever shows conformational changes in the protein due to binding of $\mathrm{Co}$ (II) complex on the negatively charged globular protein in $\mathrm{N}$ (normal) conformation [31,33,34]. After binding with $\mathrm{Co}(\mathrm{II})$ complex, change in $\mathrm{N}$ conformation to an elongated protein structure is one possibility [50]. However, the reverse kinetic shows the complex formed is not strong enough and there is a relaxation of conformation as all the excess ions are washed away by passing buffer. In this case, upon injection of analyte a compressive stress was observed on surface of microcantilever.

The maximum deflection for the ligand $\mathrm{PEG}_{12}-\mathrm{CL}$ was observed at $45 \pm 10 \mathrm{~nm}$ corresponding to a surface stress of $10.8 \pm 2.4 \mathrm{mN} / \mathrm{m}$ (Figure $3 \mathrm{~B}$ ). At $\mathrm{pH} 12$, HSA is considered to exist in A (aged) conformation which exists above $\mathrm{pH} 9$ for HAS [33,37]. Basic (B) or A conformational transition might lead to a partial unfolding in protein under basic conditions due to loss of some percentage of $\alpha$-helix [33,37,50-52]. For the injection of $\mathrm{CoCl}_{2}$ to $\mathrm{HSA}$ immobilized cantilever the maximum deflection was $102 \pm 16 \mathrm{~nm}$ (surface stress of $24 \pm 3.8 \mathrm{mN} / \mathrm{m}$ ). The analyte appears to get washed away by passing buffer solution ( $\mathrm{pH} \mathrm{12)}$ shows that there is a relaxation in protein conformation back to basic (B) or A. At $\mathrm{pH} 3$, the interaction of analyte with the immobilized protein on the microcantilever induced very low surface stress in comparison to $\mathrm{pH} 7$ and 12.The deflection of HSA immobilized microcantilever was $13 \pm 4 \mathrm{~nm}$ resulting in surface stress of $3 \pm 0.7 \mathrm{mN} / \mathrm{m}$. Whereas, at $\mathrm{pH}$ 3 the injection of $\mathrm{CoCl}_{2}$ show minimal deflection of $3 \pm 2 \mathrm{~nm}$ (surface stress $0.72 \pm 0.4 \mathrm{mN} / \mathrm{m}$ ) for the ligand.

\section{Factors affecting the $\mathrm{pH}$-dependent binding}

It is important to identify interaction between the analyte and the ligand used for immobilizationin comparison with protein under similar conditions. At various $\mathrm{pH}$ conditions the carboxyl moiety tends to have different reactivity. It can be easily perceived that at $\mathrm{pH} 7$ and $\mathrm{pH} 12$ the carboxyl terminal-group of $\mathrm{PEG}_{12}-\mathrm{CL}$ will be in deprotonated form as compared to $\mathrm{pH}$ 3. Moreover, the amide $(\mathrm{O}=\mathrm{C}-\mathrm{NH})$ group present in PEG will be protonated in presence of excess $\mathrm{H}^{+}$ions at $\mathrm{pH}$ 3. PEG chains on the surface will have intermolecular $\mathrm{H}$-bonding interactions that would rather vary under different $\mathrm{pH}$ conditions $[53,54]$. 


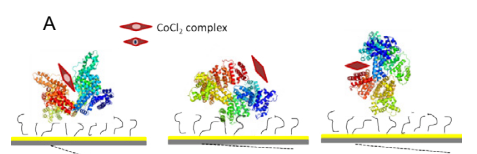

$\mathrm{pH} 7$

$\mathrm{pH} 12$
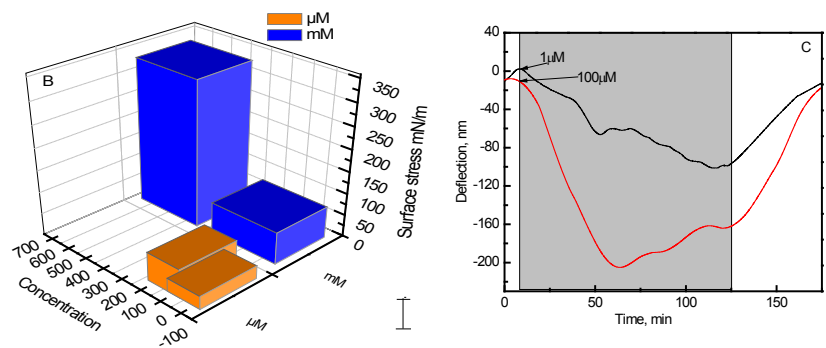

Figure 4: Schematic of deflection of cantilever at various pHsdue to induced conformational change by binding of cobalt ions $(A)$; 3D bar graph showing the difference in surface stress measured at $\mu \mathrm{M}$ (orange) and $\mathrm{mM}$ (blue) concentrations (B); Injection of micro molar concentrations showing deflection of HSA immobilized cantilevers at $\mathrm{pH} 7(\mathrm{C})$.

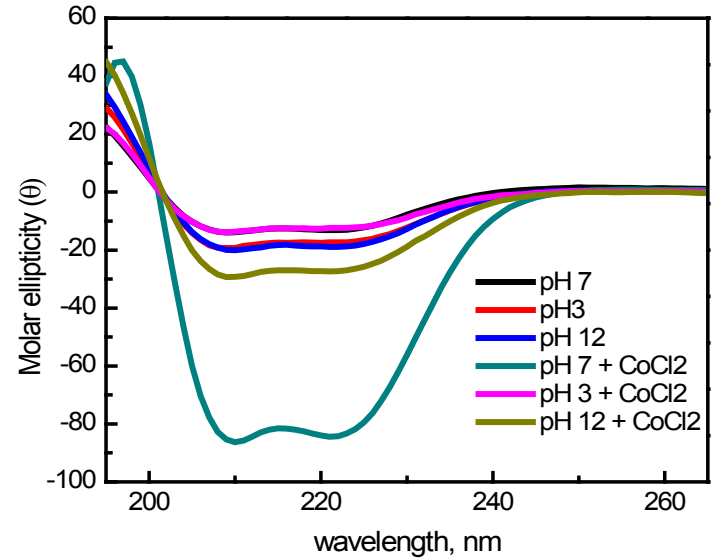

Figure 5: $\mathrm{CD}$ spectra of $\mathrm{HSA}$ with and without addition of $100 \mathrm{mM} \mathrm{CoCl}_{2}$ (5 $\mu \mathrm{L})$ at $\mathrm{pH} 7,3$ and 12 .

Therefore, at $\mathrm{pH} 7$ and 12 the surface of microcantilever will be shielded by a ligand which is negatively charged and favorable for binding with positive counter ions. The pKa value of carboxyl acids is generally between 3 and 4 [55], however $\mathrm{PEG}_{12}-\mathrm{CL}$ is a complex carboxylate ion due to electron donating PEG group, which reduces its acidity. From these results it can be concluded that at $\mathrm{pH}$ 7, HSA-Co complex is very strong in comparison with $\mathrm{pH} 3$ and 12. Conformation change in the protein structure is a consequence of change in surface charge on the protein. Protonation/deprotonation of the carboxyl terminated residues in protein results in distinct surface charge density on the immobilized protein molecules. Subsequently, there is a difference in surface charge density on the microcantilever surface immobilized with protein at various $\mathrm{pH}$ values. The Co (II) binding is influenced by charge density on the surface of the microcantilever and is therefore, influenced by conformational change of the protein that is dependent on $\mathrm{pH}$. Point to be noted is that at $\mathrm{pH} 7$ protein is negatively charged while at $\mathrm{pH}$ 3 it is positively charged [50]. Schematic representation of orientation and bending of cantilevers at various $\mathrm{pHs}$ are shown in Figure 4A. These results indicate that at $\mathrm{pH} 7$ the active sites or domains on HSA immobilized cantilevers are exposed which influence the binding of $\mathrm{Co}(\mathrm{II})$ on the surface and hence resulting in higher bending signal. Whereas, at $\mathrm{pH} 3$ the active sites may not be exposed on immobilized HSA due to N-F transition, where F is the fast conformation of HSA observed below $\mathrm{pH} 4.7,[4,5]$ resulting in lower bending signal. These results are in agreement with cobalt-albumin binding (CAB) $[19,56]$ assay showing lower binding at acidic $\mathrm{pH}$. Similarly the bending signal at $\mathrm{pH} 12$ may also be influenced by N-A transition of HSA immobilized on the surface, which might result in lower binding of $\mathrm{Co}$ (II). Another possibility may be the charge density on the surface of cantilever at $\mathrm{pH} 3$ is positive which may not allow significant binding of cations as compared to binding of cations on negatively charged protein at $\mathrm{pH} 12$.

The bending signal always shows compressive stress, this may be explained due to ionization of the backside of cantilever due to Co(II) injection at neutral acidic or basic $\mathrm{pH}$. This may allow the cantilever to bend down independent of positive or negative charge densities. Hence, the bending of the cantilever will be in such a way to increase the surface area of charged surface [33].

\section{Surface stress measurements: Influence of concentrations of $\mathrm{CoCl}_{2}$}

Since deflection of cantilever was found to be maximum at $\mathrm{pH} 7$, it was decided to run experiments at different injection concentrations at $\mathrm{pH}$ 7. Deflections of HSA immobilized microcantilever were examined between $1 \mu \mathrm{M}$ and $500 \mathrm{mM}$ at $\mathrm{pH} 7$ (Figure 4B). Deflection upon injection at lower concentration of $1 \mu \mathrm{M} \mathrm{CoCl}$ resulted in a significant change in the surface stress of $30 \pm 2.4 \mathrm{mN} / \mathrm{m}$. However, at a concentration of $100 \mu \mathrm{M}$, the surface stress was determined to be 64.8 \pm and $-4.8 \mathrm{mN} / \mathrm{m}$. Higher concentration of $\mathrm{CoCl}_{2}$ at 100 and $500 \mathrm{mM}$ resulted in surface stress of $73 \pm 10$ and $331 \pm 52 \mathrm{mN} / \mathrm{m}$, respectively. Figure $4 \mathrm{C}$ present the deflection of cantilever at 1 and $100 \mu \mathrm{M} \mathrm{CoCl}_{2}$ injections. After looking at the curves, it is worthwhile to note at lower concentrations there was complexation of $\mathrm{Co}$ (II) into intermediate states with HSA during binding kinetics.

\section{Spectroscopic analysis: CD}

Furthermore, comparison of conformational change of HSA in solution due to binding of cobalt can be easily examined with the $\mathrm{CD}$ spectroscopy (Figure 5). The CD spectra of HSA at pH 7, 12 and 3 showed prominent bands at 208 and $222 \mathrm{~nm}$, showing typical $\alpha$-helix content. The analysis of data was performed by CD pro software [57] using averaged values from SELCON and CDSSTR. The $\alpha$-helix content was analyzed as 60,54 and 54\%, for HSA at pH 7, 12 and 3, respectively. After addition of $100 \mathrm{mM} \mathrm{CoCl}_{2}(5 \mu \mathrm{L})$ in the protein sample at $\mathrm{pH} 7$, there was a significant change in $(\theta)$ value from -15 to -85 and there was a shift in negative peaks at 210 and $221 \mathrm{~nm}$ [58]. This clearly shows that there is change in conformation of the protein upon binding to cobalt complex at $\mathrm{pH}$ 7. In addition, $\mathrm{CD}$ pro analysis predicted the percentage of $\alpha$-helix to be $41 \%, \beta$-sheet structure was $6 \%$ and unordered structure was $16 \%$ after addition of $\mathrm{CoCl}_{2}$ at $\mathrm{pH} 7$. At $\mathrm{pH} 12$ and 3, the predicted a-helix content of HSA remained at 56 and $49 \%$, respectively. This shows the $\alpha$-helix content of HSA upon binding Co (II) doesn't change much at pH 12 in a liquid environment. However, upon binding to $\mathrm{Co}$ (II) we see a shift in $[\theta]$ values, indicates there may be change in other secondary structures present in the protein. The conformational change in solution is different than on a solid surface, however recently Bergese et al. and Shrotiya et al. have compared the binding of host-guest molecules using isothermal titration calorimeter (ITC) measurements in solution and on microcantilever surface that matched fairly well $[59,60]$. Similarly, if we relate the solution work with the conformational change upon 
Citation: Thakur G, Kim S, Prashanthi K, Thundat T (2014) Investigation of PH-Assisted Human Serum Albumin (HSA)-Cobalt (Co) Binding Using Nanomechanical Deflection and Circular Dichroism. J Nanomed Nanotechol S5:008. doi:10.4172/2157-7439.S5-008

Page 5 of 6

\begin{tabular}{|c|c|c|}
\hline PBS Buffer & $\begin{array}{c}\text { CD (Molar ellipticity, } \boldsymbol{\theta} \text { ) at } \\
\mathbf{2 1 0} \mathbf{~ n m}\end{array}$ & $\begin{array}{c}\text { Cantilever(surface stress, } \mathbf{m N} / \mathbf{m} \text { ) } \\
\text { at 100 } \mathbf{m i n}\end{array}$ \\
\hline pH 7 & -86 & $73 \pm 10 \mathrm{mN} / \mathrm{m}$ \\
\hline pH 12 & -29 & $24 \pm 4 \mathrm{mN} / \mathrm{m}$ \\
\hline pH 3 & -13 & $3 \pm 0.7 \mathrm{mN} / \mathrm{m}$ \\
\hline
\end{tabular}

Table 1: Relative change observed upon $\mathrm{CoCl}_{2}$ injection by spectroscopic and cantilever experiments

binding of $\mathrm{CoCl}_{2}$ to the microcantilever surface it shows various similarities. Higher surface stress upon binding to cobalt complex at $\mathrm{pH} 7$ as compared to $\mathrm{pH} 12$ and 3 is observed on microcantilever surface. Corresponding spectroscopic change of binding of cobalt with HSA through CD is relative to surface stress change both of which are predominant at $\mathrm{pH}$ 7. Table 1 shows the respective comparison of $\mathrm{CD}$ and microcantilever deflection experiments.

\section{Conclusions}

In this paper, we have investigated HSA-Co(II) binding at various $\mathrm{pH}$ values using microcantilever sensors. Binding of $\mathrm{Co}(\mathrm{II})$ on the HSA immobilized microcantilever shows the significant difference in surface stress, upon variation of $\mathrm{pH}$. At $\mathrm{pH} 7$, maximum surface stress was observed as compared to $\mathrm{pH} 12$ and $\mathrm{pH}$ 3. Binding of $\mathrm{Co}$ (II) to the immobilized protein might be a multistep pathway as was observed at low concentrations at $\mathrm{pH}$ 7. Distinct binding affinities of $\mathrm{Co}(\mathrm{II})$ with HSA were observed at various pHs using microcantilever sensors. Moreover, spectroscopic analysis suggests at pH 7, HSA-Co(II) binding leads to greater conformational change with loss of $\alpha$-helix, which complements that cantilever can be used as a tool for conformational analysis. At present, we were able to demonstrate binding of Co(II)- HAS up to $\mu \mathrm{M}$ sensitivity, which is comparable to CAB60 and ACB19 assays that are already in use. The sensitivity of the method may be increased by decreasing the buffer concentration and also by examining binding of Co(II) with HSA utilizing different buffer systems. This study reveals the significance of protein binding with metal ions influenced by $\mathrm{pH}$ at solid-liquid interface. Moreover, it shows that $\mathrm{pH}$-based sensing at solid-liquid interface such as microcantilever systems has potential for detecting cardiac biomarkers.

\section{Acknowledgements}

This work is supported by Canada Excellence Research Chair (CERC). The authors would like to thank Oil Sands and Coal Interfacial Engineering Facility (OSCIEF), Nano Fabrication Lab, Alberta Centre for Surface Engineering \& Sciences (ACSES) and Department of Chemistry at University of Alberta for providing the research facilities.

\section{References}

1. Ascenzi P, Fasano M (2010) Allostery in a monomeric protein: the case of human serum albumin. Biophys Chem 148: 16-22.

2. He XM, Carter DC (1992) Atomic structure and chemistry of human serum albumin. Nature 358: 209-215.

3. Sugio S, Kashima A, Mochizuki S, Noda M, Kobayashi K (1999) Crystal structure of human serum albumin at 2.5 A resolution. Protein Eng 12: 439-446.

4. Kragh-Hansen $U$ (1990) Structure and ligand binding properties of human serum albumin. Dan Med Bull 37: 57-84.

5. Ascenzi P, Bocedi A, Notari S, Fanali G, Fesce R, et al. (2006) Allosteric modulation of drug binding to human serum albumin. Mini Rev Med Chem 6 : 483-489.

6. Curry $S$ (2009) Lessons from the crystallographic analysis of small molecule binding to human serum albumin. Drug Metab Pharmacokinet 24: 342-357.

7. Bal W, Christodoulou J, Sadler PJ, Tucker A (1998) Multi-metal binding site of serum albumin. J Inorg Biochem 70: 33-39.
8. Ghuman J, Zunszain PA, Petitpas I, Bhattacharya AA, Otagiri M, et al. (2005) Structural basis of the drug-binding specificity of human serum albumin. J Mol Biol 353: 38-52.

9. Spector AA (1975) Fatty acid binding to plasma albumin. J Lipid Res 16: 165179

10. Sinha MK, Gaze DC, Tippins JR, Collinson PO, Kaski JK (2003) Ischemia Modified Albumin is a Sensitive Marker of Myocardial Ischemia After Percutaneous Coronary Intervention. Circulation 107: 2403-2405.

11. Roy D, Quiles J, Gaze DC, Collinson P, Kaski JC, et al. (2006) Role of Reactive Oxygen Species on the Formation of the Novel Diagnostic Marker Ischemia Modified Albumin. Heart 92: 113-114.

12. Mothes $\mathrm{E}$, Faller $\mathrm{P}$ (2007) Evidence that the principal Coll-binding site in human serum albumin is not at the N-terminus: implication on the albumin cobalt binding test for detecting myocardial ischemia. Biochemistry 46: 2267-2274.

13. Arques S, Ambrosi P (2011) Human serum albumin in the clinical syndrome of heart failure. J Card Fail 17: 451-458.

14. Sinha MK, Roy D, Gaze DC, Collinson PO, Kaski JC (2004) Role of "Ischemia modified albumin", a new biochemical marker of myocardial ischaemia, in the early diagnosis of acute coronary syndromes. Emerg Med J 21: 29-34.

15. Manini AF, Ilgen J, Noble VE, Bamberg F, Koenig W, et al. (2009) Derivation and validation of a sensitive IMA cutpoint to predict cardiac events in patients with chest pain. Emerg Med J 26: 791-796.

16. Talwalkar SS, Bon Homme M, Miller JJ, Elin RJ (2008) Ischemia modified albumin, a marker of acute ischemic events: a pilot study. Ann Clin Lab Sci 38: $132-137$

17. Ramasamy I (2011) Biochemical markers in acute coronary syndrome. Clin Chim Acta 412: 1279-1296.

18. Bar-Or D, Curtis G, Rao N, Bampos N, Lau E (2001) Characterization of the $\mathrm{Co}(2+)$ and $\mathrm{Ni}(2+)$ binding amino-acid residues of the $\mathrm{N}$-terminus of human albumin. An insight into the mechanism of a new assay for myocardial ischemia. Eur J Biochem 268: 42-47.

19. Bar-Or D, Rael LT, Bar-Or R, Slone DS, Mains CW, et al. (2008) The cobaltalbumin binding assay: insights into its mode of action. Clin Chim Acta 387: 120-127.

20. Gidenne S, Ceppa F, Fontan E, Perrier F, Burnat P (2004) Analytica performance of the Albumin Cobalt Binding (ACB) test on the Cobas MIRA Plus analyzer. Clin Chem Lab Med 42: 455-461.

21. Roger V L, Go A S, Lloyd-Jones D M, Benjamin E J, Berry J D, et al.(2012)Hear disease and stroke statistics-2012 update: a report from the American Heart Association.Circulation125: e2-e220.

22. Buchapudi KR, Huang X, Yang X, Ji HF, Thundat T (2011) Microcantileve biosensors for chemicals and bioorganisms. Analyst 136: 1539-1556.

23. Ricciardi C, Canavese G, Castagna R, Ferrante I, Ricci A, et al. (2010) Integration of microfluidic and cantilever technology for biosensing application in liquid environment. Biosens Bioelectron 26: 1565-1570.

24. Wee KW, Kang GY, Park J, Kang JY, Yoon DS, et al. (2005) Novel electrical detection of label-free disease marker proteins using piezoresistive selfsensing micro-cantilevers. Biosens Bioelectron 20: 1932-1938.

25. Hansen KM, Thundat T (2005) Microcantilever biosensors. Methods 37: 57-64

26. Braun T, Ghatkesar MK, Backmann N, Grange W, Boulanger P, et al. (2009) Quantitative time-resolved measurement of membrane protein-ligand interactions using microcantilever array sensors. Nat Nanotechnol 4: 179-185.

27. Backmann N, Zahnd C, Huber F, Bietsch A, Pluckthun A, et al. (2005) A LabelFree Immunosensor Array Using Single-Chain Antibody Fragments. Proc Nat Acad Sci USA 102: 14587-14592.

28. Yue M, Stachowiak JC, Lin H, Datar R, Cote R, et al. (2008) Label-free protein recognition two-dimensional array using nanomechanical sensors. Nano Lett 8: $520-524$.

29. Maraldo D, Garcia FU, Mutharasan R (2007) Method for quantification of prostate cancer biomarker in urine without sample preparation. Anal Chem 79 : 7683-7690.

30. Braun T, Backmann N, Vögtli M, Bietsch A, Engel A, et al. (2006) Conformationa change of bacteriorhodopsin quantitatively monitored by microcantileve sensors. Biophys J 90: 2970-2977. 
Citation: Thakur G, Kim S, Prashanthi K, Thundat T (2014) Investigation of PH-Assisted Human Serum Albumin (HSA)-Cobalt (Co) Binding Using Nanomechanical Deflection and Circular Dichroism. J Nanomed Nanotechol S5:008. doi:10.4172/2157-7439.S5-008

31. Ji HF, Gao H, Buchapudi KR, Yang X, Xu X, et al. (2008) Microcantilever biosensors based on conformational change of proteins. Analyst 133: 434-443.

32. Siqueira JR Jr, Caseli L, Crespilho FN, Zucolotto V, Oliveira ON Jr (2010) Immobilization of biomolecules on nanostructured films for biosensing. Biosens Bioelectron 25: 1254-1263.

33. Thakur G, Jiang K, Lee D, Prashanthi K, Kim S, et al. (2014) Investigation of $\mathrm{pH}$-Induced Protein Conformation Changes by Nanomechanical Deflection. Langmuir.

34. Yan X, Hill K, Gao H, Ji HF (2006) Surface stress changes induced by the conformational change of proteins. Langmuir 22: 11241-11244.

35. BashirR, Hilt JZ, Elibol O, Gupta A, Peppas N A (2002) Micromechanical Cantilever as an Ultrasensitive pH Microsensor. Appl Phys Lett 81: 3091-3093.

36. Ji HF, Hansen KM, Hu Z, Thundat T (2001) Detection of pH Variation Using Modified Microcantilever Sensors. Sensor Actuat B 72: 233-238.

37. Shaw AK, Pal SK (2008) Spectroscopic studies on the effect of temperature on $\mathrm{pH}$-induced folded states of human serum albumin. J Photochem Photobiol B Biol 90: 69-77.

38. Sader J E, White L(1993) Theoretical Analysis of the Static Deflection of Plates for Atomic Force Microscope Applications. J Appl Phys 74: 1-9.

39. Stoney GG (1909) The Tension of Metallic Films Deposited by Electrolysis Proc R Soc London Ser A 82: 172-175.

40. Godin M, Tabard-Cossa V, Grütter P, Williams P (2001) Quantitative Surface Stress Measurements using a Microcantilever. Appl Phys Lett 79: 551-553.

41. Tabard-Cossa V, Godin M, Beaulieu LY, Grütter P (2005) A differential microcantilever-based system for measuring surface stress changes induced by electrochemical reactions. Sensors and Actuat B-Chem 107: 233-241.

42. Yun M, Changyong Y, Jung N, Kim S, Thundat T, et al. (2011) Nanomechanica Thermal Analysis of Photosensitive Polymers. Macromolecules 44: 9661-9665.

43. Thakur G, Prashanthi K, Thundat T (2013) Directed self-assembly of proteins into discrete radial patterns. Sci Rep 3: 1923

44. Fragoso A, Laboria N, Latta D, O'Sullivan CK (2008) Electron permeable selfassembled monolayers of dithiolated aromatic scaffolds on gold for biosensor applications. Anal Chem 80: 2556-2563.

45. Frederix F, Bonroy K, Reekmans G, Laureyn, W, Campitelli A, et al. (2004) Reduced Nonspecific Adsorption on Covalently Immobilized Protein Surfaces Using Poly (ethylene oxide) Containing Blocking Agents. J Biochem Biophys Methods 58: 67-74

46. Harder P, Grunze M, Dahint R, Laibinis PE, Whitesides GM (1998) Molecular Conformation in Oligo (ethylene glycol)-Terminated Self-Assembled Monolayers on Gold and Silver Surfaces Determines Their Ability To Resist Protein Adsorption. J Phys Chem B 102: 426-436.
47. Pribiäł R, van Stokkum IH, Chapman D, Haris PI, Bloemendal M (1993) Protein secondary structure from Fourier transform infrared and/or circular dichroism spectra. Anal Biochem 214: 366-378.

48. Surewicz WK, Mantsch HH, Chapman D (1993) Determination of protein secondary structure by Fourier transform infrared spectroscopy: a critical assessment. Biochemistry 32: 389-394.

49. Demchenko AP (1988) Red-edge-excitation fluorescence spectroscopy of single-tryptophan proteins. Eur Biophys J 16: 121-129.

50. Saito K, Hamano K, Nakagawa M, Yugawa K, Muraoka J, et al. (2011) Conformational Analysis of Human Serum Albumin and its Non-Enzymatic Glycation Products Using Monoclonal Antibodies. J Biochem 149: 569-580.

51. Rajan RS1, Li T, Aras M, Sloey C, Sutherland W, et al. (2006) Modulation of protein aggregation by polyethylene glycol conjugation: GCSF as a case study. Protein Sci 15: 1063-1075.

52. Mysels EK, Mysels KJ (1961) Tracer Electrophoresis V. The Mobility and Charge of Human Serum Albumin at Low Concentrations and Low lonic Strengths. J Am Chem Soc 83: 2049-2055.

53. Azegami S, Tsuboi A, Izumi T, Hirata M, Dubin PL, et al. (1999) Formation of an Intrapolymer Complex from Human Serum Albumin and Poly(ethylene glycol). Langmuir 15: 940-947.

54. Somasundaran P, Krishnakumar S (1997) Adsorption of Surfactants and Polymers at the Solid-Liquid Interface. Colloids Surf A123: 491-513.

55. Dawson RMC, Elliott DC, Elliott WH (1959) Data for Biochemical Research Oxford, Clarendon Press

56. Lee E, Eom JE, Jeon KH, Kim TH, Kim E, et al. (2014) Evaluation of albumin structural modifications through cobalt-albumin binding (CAB) assay. J Pharm Biomed Anal 91: 17-23.

57. Sreerama N, Woody RW (2004) On the analysis of membrane protein circular dichroism spectra. Protein Sci 13: 100-112.

58. Wilting J, Van der Giesen WF, Janssen LHM, Weidman MM, Otagiri M (1980) The effect of albumin conformation on the binding of warfarin to human serum albumin. The dependence of the binding of warfarin to human serum albumin on the hydrogen, calcium, and chloride ion concentrations as studied by circula dichroism, fluorescence, and equilibrium dialysis. J Biol Chem 255: 3032-3037.

59. Dionisio M, Oliviero G, Menozzi D, Federici S, Yebeutchou RM, et al. (2012) Nanomechanical recognition of $\mathrm{N}$-methylammonium salts. J Am Chem Soc 134: 2392-2398.

60. Kang K, Sachan A, Nilsen-Hamilton M, Shrotriya P (2011) Aptame functionalized microcantilever sensors for cocaine detection. Langmuir 27 14696-14702.
This article was originally published in a special issue, Nanotechnology: Challenges \& Perspectives in Medicine handled by Editor(s). Dr. Malavosklish Bikram, University of Houston, USA 